\title{
The Analysis of Initial Achievement of Crosscutting Concept: Cause-Effect and Critical Thinking of Junior School Students in Ceramics Crafts- Integrated Natural Science Learning
}

\author{
Yustar Afif Priambodo ${ }^{1, *}$ Insih Wilujeng ${ }^{2,}$ Khoirul Huda $^{1,}$ Rika Nuryani \\ Suwarno $^{1}$ \\ ${ }^{1}$ Master of Natural Science Education, Faculty of Mathematics and Natural Sciences, Universitas Negeri \\ Yogyakarta, Indonesia \\ ${ }^{2}$ Department of Natural Science Education, Faculty of Mathematics and Natural Sciences, Universitas Negeri \\ Yogyakarta, Indonesia \\ *Corresponding author. Email: yustarafif.2019@student.uny.ac.id
}

\begin{abstract}
This research is aimed to analysed initial achievement of crosscutting concepts: cause-effect and critical thinking in ceramics crafts-integrated Natural Science learning. The research utilized analytical descriptive by using 32 students as the respondents. The research instrument utilized ceramics crafts-integrated test questions. The data analysis technique was performed by using quantitative percentage. The validity and reliability of the test instruments were analyzed using the Quest application. The reliability value is 0.88 which means the test instrument has high reliability. The results showed that the ability of critical thinking on the indicators of analyzing data was $51.56 \%$, evaluating $57.81 \%$, valuing towards a problem $82.81 \%$, examined inter-problem logical relationship $18.75 \%$, and drawing conclusion $51.56 \%$. While the level of understanding of crosscutting concepts on the indicators of categorizing was $28.12 \%$, examines $53.12 \%$, and predicts $56.25 \%$. Overall, students' critical thinking skills and understanding of crosscutting concepts are low. The development of science learning tools must be designed to be able to increase the understanding of cross-cutting concepts: cause \& effect and critical thinking.
\end{abstract}

Keywords: Crosscutting concepts: Cause-effect, Critical thinking, Ceramics crafts

\section{INTRODUCTION}

Era development changes rapidly, it certainly has many positive and negative effects, especially if it is used directly without sorting it out. One of negative impacts of era development if it is not controlled well is the out-dated of local culture. Local wisdom is a characteristic that comes from an area from generation to generation [1]. Indeed, local culture is not as dazzling as modern culture because it is as a traditional and past culture, and past life [2]. However, local culture is actually and identity and pride.

Indonesia is a unitary state which consists of various ethnical groups and people. Each local area has its own culture, including Klaten Regency is very strategical, which is between two big cities, such as
Jogja and Solo. Besides its natural wealth, Klaten has some tourist villages which offer local potential of Klaten area, such as centre of ceramics in Melikan Bayat, batik in Tembayat Wedi, lurik in Pedan, paper umbrella in Juwiring and agro-tourism of freshwater fishery in Polanharjo [3]. This research will use ceramics craft in Bayat as a learning material of Natural Science lesson.

Bayat ceramics has existed since 600 years ago, the era when Sunan Pandanaran learnt from Sunan Kalijaga [4], [5]. Therefore, Bayat ceramics craft is truly a heritage from the area ancestor. The centre of Bayat ceramics craft has its special characteristic that the making process uses oblique technique [5]. However, not all Bayat ceramics products can be shaped using oblique technique, but only the small to 
medium size one. According to the crafts people's statement, oblique rotation technique is usually utilized by female craftspeople. The use of oblique rotate tool is provided on figure 1 .

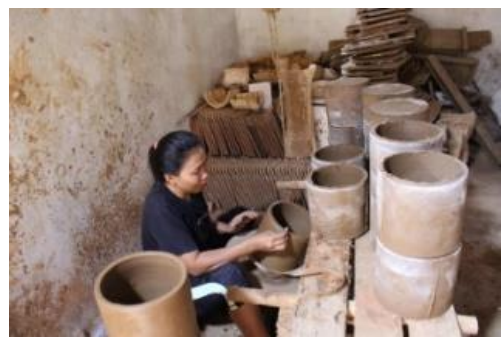

Figure 1 Bayat special oblique rotation technique

It is relevant for women who have feminism side. Ceramics produced in Bayat maintain its traditional elements, but are packed up with new nuance affected by the mind openness of Bayat ceramics craftspeople towards outsiders [6]. It means, Bayat craftspeople maintain local culture principles, but do not block themselves from accepting era development which is adjusted to their culture.

According to [6] and a craftsman's statement, generally, Bayat ceramics making techniques are as follows: (1) clay production; (2) smooth the material by using mixer until obtaining products as in figure 2 ; (3) Moisten the material with "ngeplok" method; (4) Ceramics shaping using traditional instrument as seen on figure 3. (5) Keep ceramics dried; (6) clear up the shape of ceramics; (7) apply lethoh; (8) smoothen ceramics; (9) smoothen the ceramics through "ngambu" process; (10) Dry ceramics by let it overnight, as on figure 4, (11) Ceramics firing is done by using traditional furnace; and (12) it is performed through smoke firing process by using traditional furnace with embers piled up with "munggur" leaves. The firing process utilizes traditional furnace as seen on figure 5 .

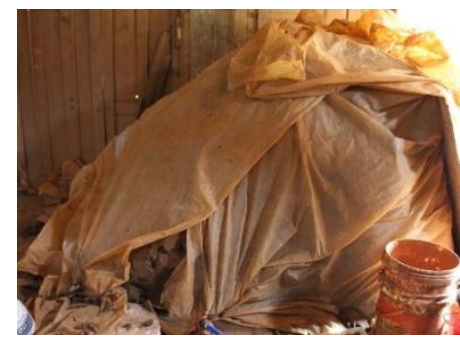

Figure 2 Bayat ceramics materials

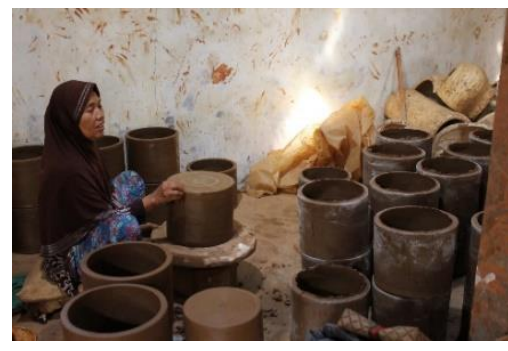

Figure 3 Bayat ceramics shaping

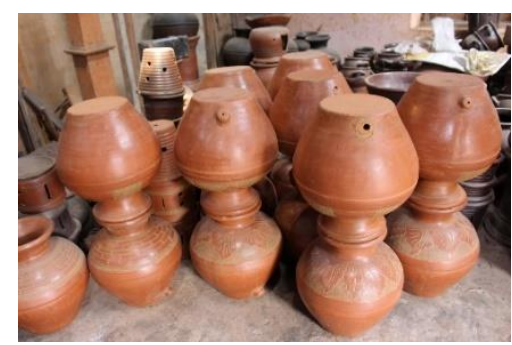

Figure 4 Process of ceramics settling for firing

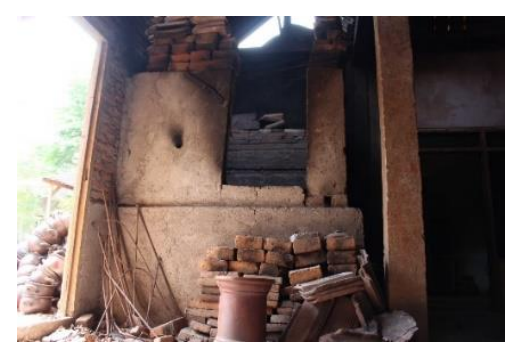

Figure 5 Firing furnace of Bayat ceramics

Natural Science is always related to the neighbourhood environment, so that various phenomena, activities or condition in the neighbourhood environment can be taken as a benefit in the Natural Science learning activities. Some local potentials in the society have been scientifically tested to be used as Natural Science teaching material [7]. The use of local potentials in the learning activities are needed, one of them is for the development of learning instrument [8], including local potential of Bayat Ceramics crafts. The closer students with environment are, the easier they are able to understand and solve a problem [9]. It indicates that local potentials in the neighbourhood environment of students support them to comprehend learning materials which are delivered.

A learning that can use local potentials as the teaching material is expected to improve the understanding of crosscutting concepts: cause-effect and critical thinking of students to respond to the era demand. Critical thinking is very important for today's developments [10]. It means that critical thinking skill is an essential thing for students to possess in facing the era development. According to [11], critical 
thinking skill of student at grade 9 of Junior High School (SMP) is categorized as low. Required learning activities that can provoke critical thinking skills [12]. Learning topic selection can also influence a learning. A learning which uses local potential is effective to increase critical thinking ability [13]. Critical thinking skill can be developed if it is continuously sharpen by connecting various knowledge to solve a problem. Dimension which is able to bridge students in connecting various concepts of problem solving are crosscutting concepts [14]. Crosscutting concept is one of NGSS dimensions [15]. This research is focussed on cause-effect aspect. It is able to provide a connection between disciplines and ideas in each topic [16].

Based on the problem, this research is aimed to analyzing initial achievement of crosscutting concepts; cause-effect and critical thinking of Junior High School (SMP) students in Klaten Regency. The indicators which are utilized for the understanding of crosscutting concepts: cause-effect are categorize, examine, and predict. Critical thinking indicators in this research are analysing data, evaluating, valuing towards a problem, examining inter-problem logical relationship, and drawing a conclusion.

\section{METHOD}

This is a descriptive quantitative research. The samples were students at Grade VII of State 1 Junior High School of Prambanan Klaten which the total respondents were 32 students. The samples were determined by simple random sampling. The test is integrated with local potential of Bayat ceramics crafts in form of online form which was distributed to students. The test was in form of multiple choices which consist of 10 of 20 questions of crosscutting concepts: cause-effect and 10 of 20 questions of critical thinking which are developed by the researcher and validated by expert lecturer. The analysis technique which was utilized in this research is descriptive analysis method. In order to see the indicators achievement, table of achievement level of each indicator is utilized and provided on table 1.

Table 1. Category of achievement level of each indicator [17]

\begin{tabular}{|c|c|}
\hline Percentage (\%) & Criteria \\
\hline $81,25<X \leq 100$ & Very high \\
\hline $71,50<X \leq 81,25$ & High \\
\hline $62,50<X \leq 71,50$ & Moderate \\
\hline $43,75<X \leq 62,50$ & Low \\
\hline $0<X \leq 43,7$ & Very low \\
\hline
\end{tabular}

\section{RESULTS AND DISCUSSION}

\subsection{Description of Students' Critical Thinking}

Critical thinking has a very important role for students' future success, including the ability to solve a problem [18]. Critical thinking has become a basic ability that should be possessed by the students to overcome the challenge of a more developing time change. In order to measure critical thinking skills of the students, this research adopts some indicators of critical thinking skills to be reorganize and adjusted with the materials and integrated with Bayat ceramics crafts. The instruments of critical thinking test that has been done by students will furthermore is analysed for each emerging indicators.

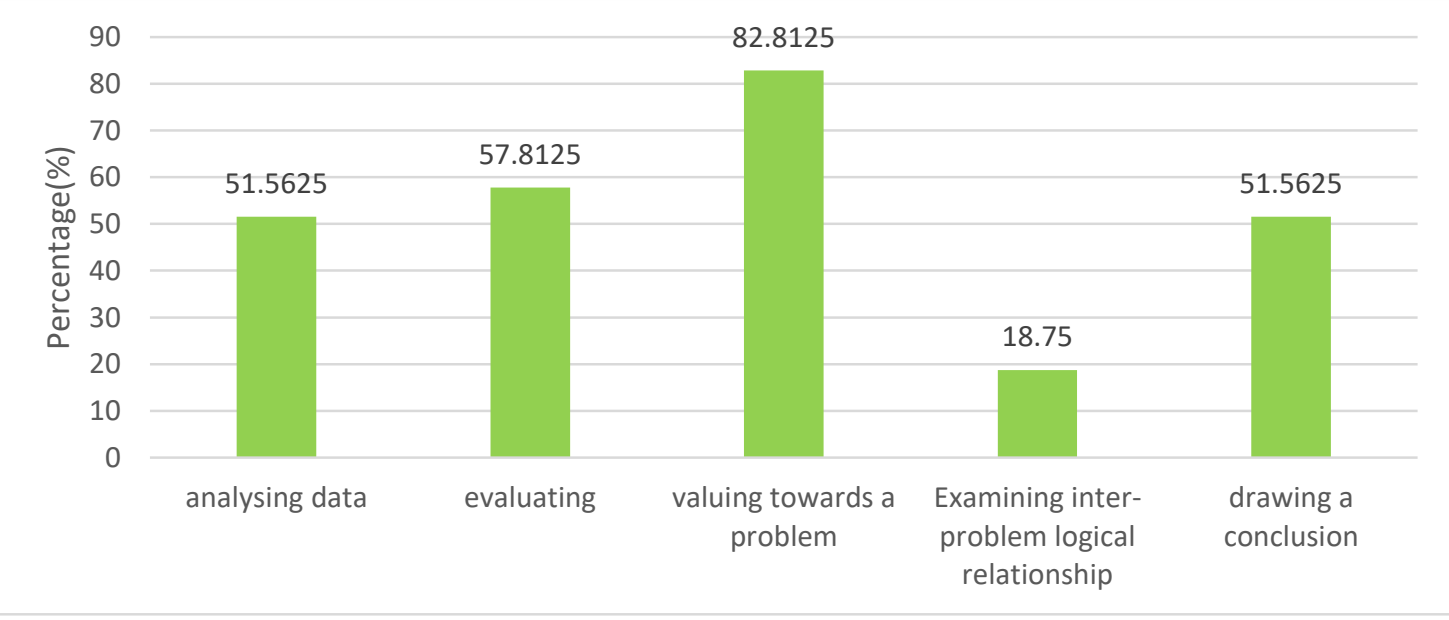

Figure 6 Percentage of student in each indicatior of critical thinking ability 
Based on figure 6, it is known that the percentage of students who correctly answered on indicator of analysing data $51.56 \%$, evaluating $57.81 \%$, valuing towards a problem $82.81 \%$, examine logical connection among problems $18.75 \%$, and drawing a conclusion $51.56 \%$.

\subsubsection{Analyzing Data}

Based on figure $6,52.56 \%$ of 32 students answer the question correctly on indicator of analysing data. This number is equal to the final indicator, which is drawing a conclusion. It means that students' ability in analysing data is categorized as low. If it is seen from the numbers of students who answer correctly on the indicator of analysing data has only a half little more of the total respondents. It is in line with the research [19] that found low categorized students' analysing ability. The analysis will certainly not develop if it's not sharpened continuously.

\subsubsection{Evaluating}

Evaluation ability is related to an ability to provide a valuation towards solution and methods which are utilized in answering questions and criticising arguments [20]. The process of valuing or evaluating is a step before drawing a conclusion [21]. Students who answer the indicator of evaluating correctly has $57.81 \%$. It means that students' evaluating ability is categorized as low. The evaluating ability is defined as a method to identify strengths and weakness in our mind [22]. The ability of evaluating can be categorized in high level thinking skill because it is able to value strengths and weakness. Therefore, the ability to evaluate students should be improved.

\subsubsection{Valuing Towards A Problem}

Students' ability to value a problem indicates $82.81 \%$. Therefore, their ability in valuing a problem is categorized as high. It is in line with [23] who stated that the ability to value an information which is critical thinking skills indicator indicates an excellent critical thinking skills. However, the students' ability to value a problem must be improved. No matter how high the score is, the ability must be honed. It is important to bring up a case/ issue in the students' learning activity so they are accustomed to value an issue scientifically. Certainly, the concrete issue exists around the students will enable them to value scientifically.

\subsubsection{Examining Inter-Problem Logical Relationship}

The students' ability of examining inter-problem logical relationship at State 1 Junior High School Prambanan Klaten indicates $18.75 \%$ which is categorized in a very low category. It is in line with the research [24] that stated students are less able to examine. The examining ability of inter-problem logical relationship is very crucial to be possessed by students because by examining, they will understand information as a whole. The process of examining can develop thinking, opinion, imagination and creativity of students [25]. Therefore, in understanding a problem, students can see logically.

\subsubsection{Drawing A Conclusion}

Students' ability in drawing a conclusion is on the percentage $51.56 \%$. The number is equal as on the first, which is analysing data. The students' ability of drawing a conclusion is categorized as low. It is different with the finding of [26] that stated their concluding ability is categorized as moderate. While [8] stated the initial ability of drawing a conclusion that the indicator of critical thinking skills of students of Junior High School in Jepara is categorized as low. The ability of drawing a conclusion is very important because it equips students to understand an information. Therefore, learning activity to improve students' concluding ability is required.

\subsection{Description of Students' Crosscutting Concepts: Cause-Effect Understanding [27]}

The intended relationship is a cause and effect relationship, so the students are able to scrutinize cause and effect of an event. In order to measure students' crosscutting effect: cause-effect, this research adopts Crosscutting effect: cause-effect indicator from NGSS to reorganize and adjusted with material and be integrated with Bayat ceramics crafts. Test instrument of each crosscutting effect: causeeffect indicator that is performed by students is analysed.

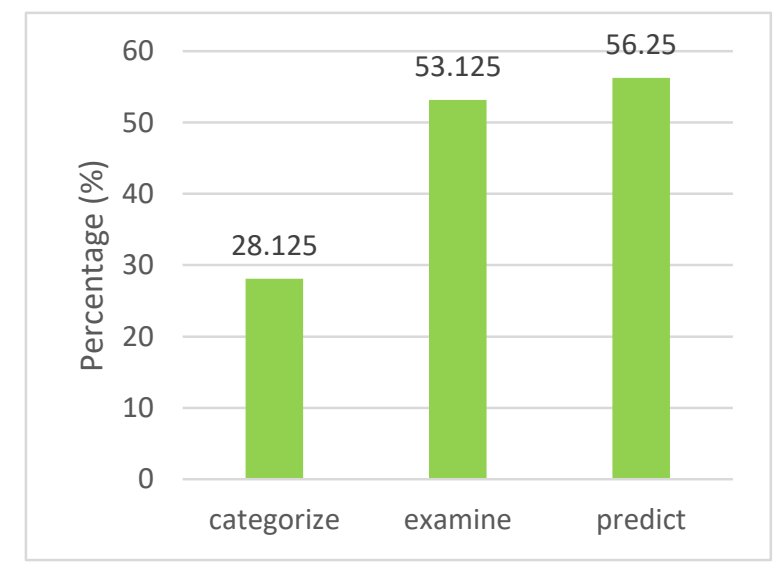

Figure 7 Percentage of student in each indicator of crosscutting effect: cause-effect ability 


\subsubsection{Categorizing}

The categorizing ability of Students of Junior High School Klaten indicate percentage of $28.12 \%$ which is low category. The ability of categorizing should be improved as the students' provision to face era development. It is in line with [28] that state categorizing ability of students are considered as low. It is also the lowest percentage of the other three indicators of crosscutting effect: cause-effect, which has $28.13 \%$ in difference compared to the highest percentage indicator, predicting.

\subsubsection{Examining}

The students' examining ability on crosscutting effect: cause-effect indicator is on percentage 53.12\%, which is categorized as low. It is in line with research [24] that find students' examining ability is low. Examining process is an important process that must be undergone by students when understanding the information obtained so they are able to sort it out. Examining process is able to develop mind, opinion, imagination, and creativity of students [25]. Mind development in examining activity does not merely come from institution but in-depth thinking process. Therefore, an ability to examine students should be improved.

\subsubsection{Predicting}

Predicting ability on indicator of crosscutting effect: cause-effect indicates $56.25 \%$ that is categorized as low. Predicting ability must certainly be improved to meet era development. It is irrelevant with [29] that students' predicting ability is categorized as moderate to high. Learning activity should be adjusted as an instrument to improve students' predicting ability. Therefore, this research integrates Bayat ceramics crafts in Natural Science Learning.

\section{CONCLUSION}

The conclusion of research on the analysis of initial achievement of Junior High School Students' crosscutting concepts: cause-effect and critical thinking in Natural Science learning indicates the level of understanding of both crosscutting concepts: causeeffect $\&$ critical thinking skills are low.

\section{REFERENCES}

[1] E. Priyambodo, S. Wulaningrum, Using Chemistry Teaching Aids Based Local Wisdom as An Alternative Media for Chemistry Teaching and Learning, International Journal of Evaluation and Research in Education 6(4) (2017) 295-298. DOI: https://doi.org/10.11591/ijere.v6i4.10772

[2] J. Sutarso, Local Culture-Based Social Media Literation: Local Culture Content on Social Media as St-Rengthening Social Integration, Profetik: Jurnal Komunikasi 13(1) (2020) 74-86. DOI: https://doi.org/10.14421/pjk.v13i1.1742.

[3] J. Prasetyo, W.S. Irwanto, Pemetaan Posisi Daya Saing Desa Wisata di Kabupaten Klaten Berbasis Otentitas Potensi Lokal, in: Prosiding Seminar Nasional Tahun 2018: Publikasi Hasil Penelitian dan Pengabdian Masyarakat, vol. 1, Universitas Veteran Bangun Nusantara Sukoharjo, Sukoharjo, 2019, pp. 279-289,

[4] P. Yustana, Bayat Ceramic (Aesthetic, Form, and Function), Acintya: Jurnal Penelitian Seni Budaya 6(1) (2014) 14-32, https://doi.org/10.33153/acy.v6i1.179

[5] A. Suharson, D.A. Asmara, Komposisi Tanah Untuk Teknik Reproduksi Keramik Di Sentra Gerabah Pagerjurang Klaten, Corak: Jurnal Seni Karya 1(1) (2012) 1-10. DOI: https://doi.org/10.24821/corak.v0i0.289

[6] W. Safitri, T.H. Retnowati, B. Prihadi, Creative ceramics of Bayat Klaten: Craft development in a postmodern context, in: Advances in Social Science, Education and Humanities Research, vol. 444, Atlantis Press, Piscataway, New Jersey, 2019, pp. 34-40. DOI: https://dx.doi.org/10.2991/assehr.k.200703.008

[7] Parmin, Sajidan, Ashadi, Sutikno, Y. maretta, Preparing Prospective Teachers in Integrating Science and Local Wisdom through Practicing Open Inquiry, Journal of Turkish Science Education 13(2) (2016) 3-14. DOI: https://doi.org/10.12973/tused.10163a

[8] A. Anisa, Meningkatkan Keterampilan Berpikir Kritis Peserta Didik Melalui Pembelajaran IPA Berbasis Potensi Lokal Jepara, Jurnal Inovasi Pendidikan IPA 3(1) (2017) 1-11. DOI: https://doi.org/10.21831/jipi.v3i1.8607

[9] A.S. Ardan, The Development of Biology Teaching Material Based on The Local Wisdom of Timorese to Improve Students Knowledge and Attitude of Environment In Caring the Persevation of Environment, International Journal of Higher Educationa 5(3) (2016) 190200. DOI: https://doi.org/10.5430/ijhe.v5n3p190 
[10] H. Xu, D. Huang, J. Leng, X. Xu, Investigating the developmental trajectory of critical thinking in online discourse among college students : an epistemic network analysis, in: Proceedings of The $14^{\text {th }}$ International Conference of The Learning Sciences (ICLS), vol. 14, International Society of The Learning Sciences, Bloomington, Indiana, 2020, pp. 509-512. DOI: https://doi.dx.org/10.22318/icls2020.509

[11] S. Syahmel, J. Jumadi, Discovery Learning Using Multiple Representation Model for Enhancing Scientific Processing and Critical Thinking Skills of The Students Jurnal Inovasi Pendidikan IPA 5(2) (2019) 180-194. DOI: https://doi.org/10.21831/jipi.v5i2.26704

[12] A. Syarkowi, The effect of reading assignments in guided inquiry learning on students' critical thinking skills, in: Journal of Physics: Conference Series, vol. 1013, IOP Publishing, Bristol, 2018, pp. 1-6. DOI: https://doi.org/10.1088/1742$\underline{6596 / 1013 / 1 / 012078}$

[13] N. Anggraeni, Suryanti, W. Budijastuti, Development of Student Activity Sheets Based on Local Wisdom to Improve Critical Thinking Skills of Science 4th Grade Elementary School, International Journal of Innovate Science and Research Technology 5(7) (2020) 952-958. DOI: https://doi.org/10.38124/ijisrt20jul690

[14] T. Slominski, A. Fugleberg, W.M. Christensen, J.B. Buncher, J.L. Momsen, Using Framing as a Lens to Understand Context Effects on Expert Reasoning, CBE Life Science Education 19(3) (2020) 1-16. DOI: https://doi.org/10.1187/cbe.19-11-0230

[15] CCSSO, Using Crosscutting Concepts to Prompt Student Responses, Council Chief State School Officer, 2018.

[16] Rahmita, D. Rosana, Profile analysis of data literacy capability based on NGSS junior high school students in Takalar, South Sulawesi, in: Journal of Physics: Conference Series, vol. 1440, IOP Publishing, Bristol, 2020, pp. 1-5. DOI: https://doi.org/10.1088/17426596/1440/1/012082

[17] Ermayanti, D. Sulisworo, Tingkat kemampuan berpikir kritis peserta didik setelah penerapan model pembelajaran student team achievement divisions (STAD) pada siswa sekolah menengah atas (SMA), in: Prosiding Seminar Nasional
Quantum, vol. 1. Universitas Ahmad Dahlan, Yogyakarta, 2016, pp. 175-181,

[18] S. Nawawi, Developing of Module Challenge Based Learning in Environmental Material to Empower The Critical Thinking Ability, Jurnal Inovasi Pendidikan IPA 3(2) (2017) 212-223. DOI: http://dx.doi.org/10.21831/jipi.v3i2.15988

[19] F. Inggriyani, N. Fazriyah, Analisis Kemampuan Berpikir Kritis Siswa dalam Pembelajaran Menulis Narasi di Sekolah Dasar, Jurnal Pendidikan Dasar 9(2) (2018) 30-41. DOI: https://doi.org/doi.org/10.21009/JPD.092.04

[20] D. Kurniati, R. Harimukti, N.A. Jamil, Kemampuan Berpikir Tingkat Tinggi Siswa SMP di Kabupaten Jember dalam Menyelesaikan Soal Berstandar PISA, Jurnal Penelitian Dan Evaluasi Pendidikan 20(2) (2016) 142-155. DOI: https://doi.org/10.21831/pep.v20i2.8058

[21] N.D.L. Dewi, Z.K. Prasetyo, Pengembangan Instrumen Penilaian IPA untuk Memetakan Critical Thinking dan Practical Skill Peserta Didik SMP, Jurnal Inovasi Pendidikan. IPA 2(2) (2016) 213-222. DOI: https://doi.org/10.21831/jipi.v2i2.11963

[22] V. Makhzoum, M. Jabbour, Critical Thinking and It Is Role in Facing Coronavirus, International Journal Of Education Research Review 5(4) (2020) 389-406. DOI: https://doi.org/10.24331/ijere.770575

[23] R.A. Nugroho, I. G. P. Suryadarma, Pengaruh Servant Leadership Learning dengan Concept Mapping terhadap Pemahaman Konsep dan Berpikir Kritis Siswa, Jurnal Inovasi Pendidikan IPA 4(1) (2018) 114-127. DOI: http://dx.doi.org/10.21831/jipi.v4i1.9823

[24] L. Yuliawati, C. Hasanudin, Analisis Penelaahan Puisi Rakyat Dengan Strategi, Jurnal Ilmiah Semantika 2(1) (2020) 21-27. DOI: https://doi.org/10.46772/semantika.v2i01.260

[25] S. Maryani, B.D. Milandari, M.S. Dewi, Analisis Kemampuan Menelaah dan Merevisi Teks Deskripsi, Paedagoria: Jurnal Kajian, Penelitian, dan Pengembangan Kependidikan 10(1) (2019) 16-23.

DOI: https://doi.org/10.31764/paedagoria.v10i1.815

[26] Y. Erawati, U. Azizah, Developing Encyclopedia Media on Form and Function of Plant to Train Elementary Students' Critical Thinking Skill, International Journal for 
Education and Vocational Studies 2(6) (2020) 401-406.

DOI: https://doi.org/10.29103/ijevs.v2i6.2514

[27] A.E. Rivet, G. Weiser, X. Lyu, Y. Li, D. RojasPerilla, What are crosscutting concepts in science? Four metaphorical perspectives, in: Proceedings of The $12^{\text {th }}$ International Conference of The Learning Sciences, vol. 2, International Society of The Learning Sciences, Bloomington, Indiana, 2016, pp. 970-973. DOI: https://doi.dx.org/10.22318/icls2016.149.
[28] Tasiwan, S.E. Nugroho, Hartono, Pengaruh Advance Organizer Berbasis Proyek Terhadap Kemampuan Analisis - Sintesis Siswa, Jurnal Pendidikan Fisika Indonesia 10(1) (2014) 1-8. DOI: https://doi.org/10.15294/jpfi.v10i1.3044

[29] F.O. Rosa, Eksplorasi Kemampuan Kognitif Siswa terhadap Kemampuan Memprediksi, Mengobservasi dan Menjelaskan Ditinjau dari Gender, Jurnal Pendidikan Fisika FKIP UM Metro 5(2) (2017) 111-118. DOI: http://dx.doi.org/10.24127/jpf.v5i2.987 